\title{
Marketing Mix is The Only Variable to Choose Brands and Quality?
}

\author{
Umbas Krisnanto \\ Perbanas Institute Jakarta
}

\section{ART I C L E IN F O \\ Keywords: \\ marketing mix, \\ family, \\ brand equity, \\ perceived quality}

Corresponding author:

umbas@perbanasinstitute.ac.id
A B S T R A C T

This research is to find out how the role and influence of marketing stimuli (advertising, pricing, and sales promotion) as well as the role of family and brand awareness, brand associations, perceived quality of Pepsodent toothpaste. The benefits of this research study is expected to be considered in developing a marketing mix that ultimately led to the formation of perceived qualitys. Second, updating the theory of consumer behavior and marketing theory. This research method is accomplished by using a descriptive study using survey. The population in this study is consumer of Pepsodent toothpaste. Samples done by accidental sampling. For data collection questionnaire used closed type. Operationalization variable using descriptive and quantitative analysis variable (GSCA and SEM). The results showed the influence of very low ranging from 0.00 to 0.19 for the relationship of advertising and brand awareness variables, the price and brand association variables, promotion and brand awareness variables, relationship between family variable and brand awareness and brand association. While family variable and perceived quality variable had reverse effect. The low but definite effect ranged from 0.20 to 0.39 for the advertising variable, brand associations variable, and perceived quality as well as variable promotion, promotional variable to variable brand associations and perceived quality variables. The effect was ranged from 0.40 to 0.60 for brand awareness and perceived quality variables. Recommendations to PT Unilever should deliver more competitive promotion thus proving that good quality is always supported by good and great promotion, low price version. Pepsodent should promote impressed with quality, still showing the previous experience of the people who have benefited from Pepsodent, while providing marketing and advertising top of mind to their customers so that they lose sight of the Pepsodent, still suggested best quality can be compared with its competitors, the evidence suggests that the quality is always the best

(C) 2013 IRJBS, All rights reserved. 


\section{INTRODUCTION}

Brand advertising had impact on potential buyers' implicit memory (Buschken, 2007). Spending on brand advertising will increase the coverage and repetition of advertising messages, and as a result, a higher level of awareness will be obtained for a given brand. Jeong (2004) had found advertising contributed directly to brand equity. Advertising spending by consumers also felt positive about the brand equity as evidenced in previous works (Villarejo \& Sanchez-Franco, 2005). Branding is considered means in establishing and maintaining competitive advantage (Deepa \& Chitramani, 2013). Family has been regarded as one of the strong factors in consumer behavior. Research on brand equity, from a consumer perspective, aiming to analyze the behavior of consumers towards the brand name (Keller, 2003). Perceived quality is considered as a consumer judgment about the overall excellence or superiority of the product. Companies should communicate the quality of the signal quality of the brand through marketing actions. Consumers feel brand equity through their direct experience with the brand and the information obtained in environmental factors (Boonghee Yoo, Donthu, \& Lee, 2000). Perceived quality had significant influence on the brand loyalty (Shaharudin, Mansor, Hassan, Omar, \& Harun, 2011). Among the extrinsic attributes of marketing through advertising, pricing and promotion, have a major role. High advertising spending, high price, good store image, and high distribution intensity are related to high brand equity (Boonghee Yoo et al., 2000), so that, there is a positive relationship between advertising expenditure and consumer perceived of brand quality. Information provided by the family brand to determine consumer perceiveds of the quality of a brand. Thus, young people's perceived of the brand recommended or used by other experienced consumers, may influence the perceived quality of the brand. Family had joint activity, and children's active participation, determines the influence they gain (Norgaard, Bruns, Christensen, \& Mikkelsen, 2007). This perceived involves a more positive attitude toward the brand, and may result in the purchase of the brand (Moore, Wilkie, \& Lutz, 2002). High quality producers should raise the price to signal quality. Thus, the high price is generally regarded as higher quality than the cheap price. This has been outlined in the study Chiang and Niu (2013). Along the same argument, price promotions may erode brand quality because they reduce the price of the product (Jorgensen, Taboubi, \& Zaccoure, 2003). Negative effect of sales promotion anticipated adverse effects on brand equity (Swait \& Erdem, 2022), which results in a negative perceived of the brand. The influence the assets of brand equity is brand association, brand awareness, perceived quality, and brand loyalty (Bohrer, 2007). Every new experience in creating brand, strengthen or modify individual associations.

Research objectives is to find out how the role of marketing stimuli (advertising, pricing, and sales promotion) as well as the role of the family and brand awareness, brand associations, as well as perceiveds of the quality of the Pepsodent toothpaste. Second, to determine the effect of advertising, price, family, sales promotion, the brand awareness, brand associations and perceived quality on Pepsodent toothpaste

Benefits of this research is expected of what factors to consider in developing marketing mix that ultimately led to the formation of perceived qualitys. Second, make a good present from the theory of consumer behavior and marketing theory.

\section{Theoretical Framework}

Previous studies can be summarized as shown in Table 1.

\section{METHODS}

The study was conducted by using a descriptive study using survey. The population in this study is the Pepsodent toothpaste users. The sampling method was done by accidental sampling number 
Table 1: Previous Studies

\begin{tabular}{|c|c|c|c|c|}
\hline \multirow{2}{*}{ Variable } & \multirow{2}{*}{ Influenced to } & \multicolumn{3}{|c|}{ Studied by } \\
\hline & & Gilaninia & Yoo & Gil \\
\hline \multirow{3}{*}{ Advertising } & Brand Awareness & 0,18 & 0,34 & 0,19 \\
\hline & Brand Associations & 0,23 & 0,34 & 0,19 \\
\hline & Perceived quality & $-0,05$ & 0,35 & 0,20 \\
\hline \multirow{3}{*}{ Price } & Brand Awareness & & $-0,21$ & \\
\hline & Brand Associations & & $-0,21$ & \\
\hline & Perceived quality & & 0,09 & 0,22 \\
\hline \multirow{3}{*}{ Family } & Brand Awareness & 0,77 & & 0,65 \\
\hline & Brand Associations & 0,75 & & 0,65 \\
\hline & Perceived quality & 0,81 & & 0,45 \\
\hline \multirow{3}{*}{$\begin{array}{c}\text { Sales } \\
\text { Promotion }\end{array}$} & Brand Awareness & & & \\
\hline & Brand Associations & & & \\
\hline & Perceived quality & & & $-0,01$ \\
\hline
\end{tabular}

Source: Gilaninia, Delafrooz, and Dokht (2012), B. Yoo and Dontu (2001), Gil, Andres, and Salinas (2007)

of respondents who were sampled 200 people. Data collection using closed type questionnaire.

Validity test instrument that measure all the variables are valid because $r$ value larger than $r$ table. Reliability test instrument are all reliable.

Multi relationship analysis could be grouped into recursive and non recursive. Besides indicators of latent variable models exist that is reflective and formative. Analysis of the structural equation modelling (SEM) has only drawback could be used to analyze the structural model of reflective indicator models. While the partial least square (PLS) analysis has weaknesses because only can be used on recursive structural models. If a study analyzing the structural model is not recursive and formative indicators, the SEM and PLS analyzes can not be used. The solution is to use structured generalized component analysis (GSCA). (David, 2014)

\section{RESULTS AND DISCUSSION}

\section{Descriptive Analysis}

Advertising Variable. Based on descriptive calculation of advertising indicator, that the amount of the budget indicators and the product life cycle, it can be said that the dimensions of the advertising budget in good scale. Based on the frequency and cost level indicator ad campaign, it can be said that the frequency dimension in good scale. Based on the cost and quality indicators better than competitors, it can be said that the dimensions of avertising cost effectiveness in good scale.

Price Variable. Based on descriptive calculation of pricing indicator, that high price reflection of high quality. Based on lowering-price could increasing demand but will limiting supply indicators, that the dimension of lowering price could increasing demand sufficiently. 
Table 2: Operationalization Variable

\begin{tabular}{|c|c|c|}
\hline Variable & Dimension & Indicator \\
\hline \multirow{6}{*}{ Advertising } & \multirow{2}{*}{$\begin{array}{l}\text { a. Advertising } \\
\text { budget }\end{array}$} & 1. The amount of advertising budget \\
\hline & & 2. Budget corresponding to product lifecycle \\
\hline & \multirow{2}{*}{$\begin{array}{l}\text { b. Advertising } \\
\text { frequency }\end{array}$} & 3. Level of frequency \\
\hline & & 4. Advertising campaign more than competitors \\
\hline & \multirow{2}{*}{$\begin{array}{l}\text { c. Effectivity } \\
\text { advertising } \\
\text { promotion cost }\end{array}$} & 5. Advertising cost greater than competitors \\
\hline & & 6. Advertising quality is better than competitors \\
\hline \multirow{6}{*}{ Price } & \multirow{2}{*}{$\begin{array}{l}\text { a. High } \\
\text { price }\end{array}$} & 7. Although the price high consumer remains buy it \\
\hline & & 8. High price indicates high quality \\
\hline & \multirow{2}{*}{$\begin{array}{l}\text { b. Lower } \\
\text { Price }\end{array}$} & 9. Even lower price, consumer still buy it \\
\hline & & 10. Excess supply causes low prices \\
\hline & \multirow{2}{*}{$\begin{array}{l}\text { c. Expensive } \\
\text { price }\end{array}$} & 11. Prices rise, consumers moving to other brands \\
\hline & & 12. Expensive prices cause demand to decline \\
\hline \multirow{6}{*}{ Promotion } & \multirow{2}{*}{$\begin{array}{l}\text { a. Promotion } \\
\text { frequency }\end{array}$} & 13. Level of promotion frequency \\
\hline & & 14. Level of promotion sufficiency \\
\hline & \multirow{2}{*}{$\begin{array}{l}\text { b. Promotion } \\
\text { reach }\end{array}$} & 15. Level of promotion reach \\
\hline & & 16. Complete information of promotional activities \\
\hline & \multirow{2}{*}{$\begin{array}{l}\text { c. Promotion } \\
\text { cost }\end{array}$} & 17. Promotion costs more expensive than competitors \\
\hline & & 18. Promotion quality better than competitors \\
\hline \multirow{12}{*}{ Family } & \multirow{2}{*}{$\begin{array}{l}\text { a. Long term } \\
\text { purchase }\end{array}$} & 19. Families bought the same product for a long time \\
\hline & & 20. Purchases continuously \\
\hline & \multirow{2}{*}{$\begin{array}{l}\text { b. Intention to } \\
\text { buy }\end{array}$} & 21. My parents bought the product in different occasion \\
\hline & & 22. Keep buying even though in stock \\
\hline & \multirow{2}{*}{$\begin{array}{l}\text { c. Brand } \\
\text { loyalty }\end{array}$} & 23. Product consumed from a long time ago \\
\hline & & 24. Using the same brand continously \\
\hline & \multirow{2}{*}{$\begin{array}{l}\text { d. Parent role } \\
\text { to buy products }\end{array}$} & 25. Parents role for buying family matters \\
\hline & & $\begin{array}{l}\text { 26. Remained used the brand although had moved from parents } \\
\text { home }\end{array}$ \\
\hline & \multirow[t]{2}{*}{ e. Parent role } & 27. Parents always argue that the product is the best ever \\
\hline & & 28. The hardest parents influence of products selection \\
\hline & \multirow{2}{*}{$\begin{array}{ll}\text { f. } & \text { Parent } \\
& \text { recommen } \\
& \text { dation }\end{array}$} & 29. Parents recommend products for family \\
\hline & & 30. The selection of products always consulted to parents \\
\hline
\end{tabular}




\begin{tabular}{|c|c|c|}
\hline \multirow{6}{*}{$\begin{array}{c}\text { Brand } \\
\text { Awareness }\end{array}$} & \multirow{2}{*}{$\begin{array}{l}\text { a. Top of } \\
\text { mind }\end{array}$} & 31. This is the first brand in mind \\
\hline & & 32. This is the most remembered brand in mind \\
\hline & \multirow[t]{2}{*}{ b. Brand recognition } & 33. This brand is easy to recognized \\
\hline & & 34. This brand had a hallmark \\
\hline & \multirow{2}{*}{$\begin{array}{l}\text { c. Brand } \\
\text { pressence }\end{array}$} & 35. The most recognized brand presence \\
\hline & & 36. This is the most known brand than other brands \\
\hline \multirow{8}{*}{$\begin{array}{c}\text { Brand } \\
\text { Association }\end{array}$} & \multirow{2}{*}{$\begin{array}{l}\text { a. Brand } \\
\text { impression }\end{array}$} & 37. This brand had a positive impression for consumers \\
\hline & & $\begin{array}{l}\text { 38. This brand has a strong characteristic so that is easy to } \\
\text { remember }\end{array}$ \\
\hline & \multirow{2}{*}{$\begin{array}{l}\text { b. Brand } \\
\text { differentation }\end{array}$} & 39. Consumers easily distinguish one brand to another \\
\hline & & 40. This brand had higher quality than competitors \\
\hline & \multirow{2}{*}{$\begin{array}{l}\text { c. Brand } \\
\text { recall }\end{array}$} & 41. Consumers easily recall the brand logo or symbol \\
\hline & & 42. This brand had known since long time \\
\hline & \multirow[t]{2}{*}{ d. Brand personality } & 43. This brand has a strong personality \\
\hline & & 44. This is a flagship brand family \\
\hline \multirow{6}{*}{$\begin{array}{l}\text { Perceived } \\
\text { quality }\end{array}$} & \multirow{2}{*}{$\begin{array}{l}\text { a. Best } \\
\text { quality }\end{array}$} & 45. No doubt about this quality \\
\hline & & 46. This product has the best quality compared to competitors \\
\hline & \multirow[t]{2}{*}{ b. Trust } & 47. Had a high confidence using this product \\
\hline & & 48. This high-quality product is able to convince consumers \\
\hline & \multirow{2}{*}{$\begin{array}{l}\text { c. High } \\
\text { quality }\end{array}$} & 49. The product quality is higher than similar products \\
\hline & & 50. This quality product is more guaranteed than competitors \\
\hline
\end{tabular}

Source: Boonghee Yoo et al. (2000)

Table 3: Structural equation modelling assumption

\begin{tabular}{lc}
\hline Chi-square (p value) & $>0.05$ \\
\hline RMR (root mean squared residual) & $<0.05$ \\
\hline RMSEA (root mean squared error of approximation) & $<0.05$ \\
\hline GFI (goodness-of-fit index) & $>0.9$ \\
\hline AGFI (adjusted goodness-of-fit index) & $>0.9$ \\
\hline CFI (comparative fit index) & $>0.9$ \\
\hline TLI (Tucker-Lewis Index) & $>0.9$ \\
\hline
\end{tabular}

Ghozali (2004) 
Table 4: The relationship variables studied

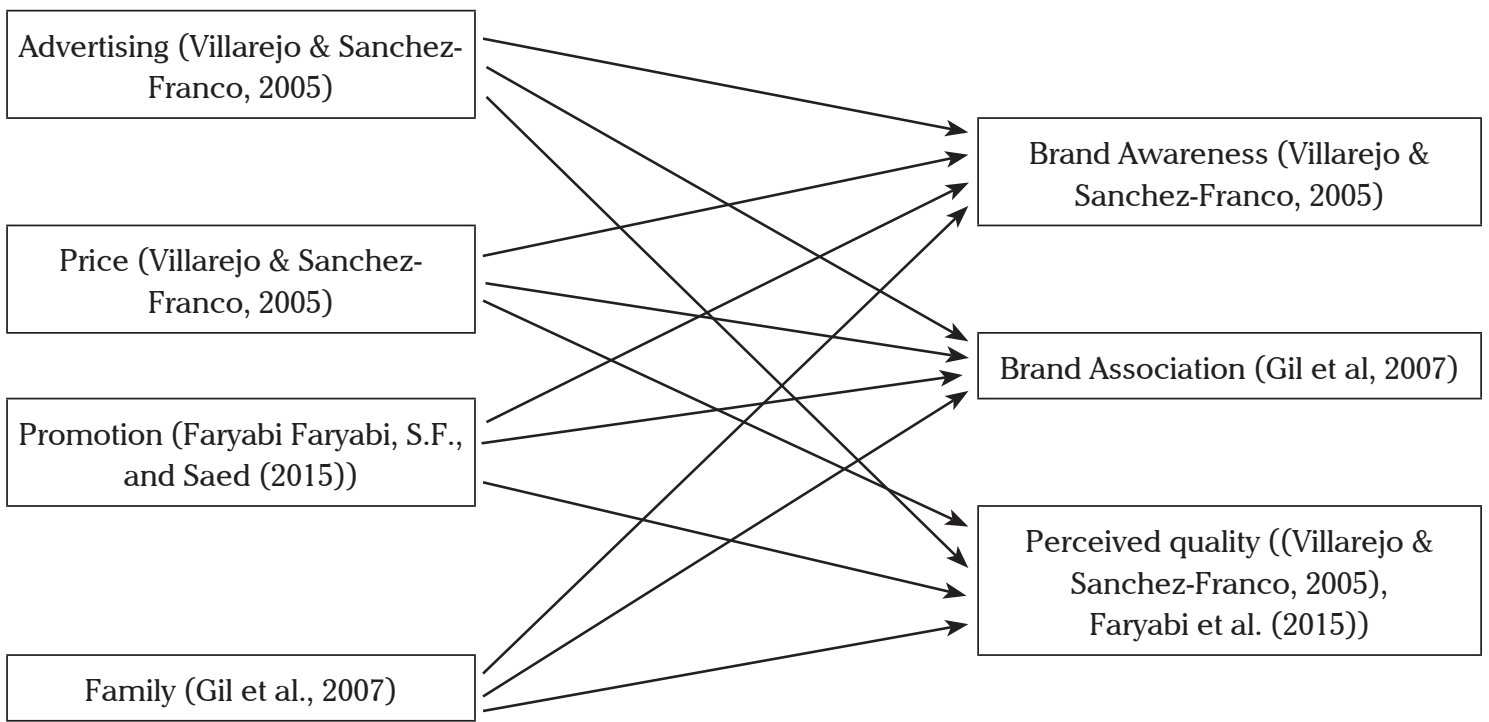

Promotion Variable. Based on descriptive calculation of promotion indicators, that promotion dimension has a high frequency. Based on the level indicator and promotional activities, that the promotion had already reaching out to the entire community. Cost and quality promotion indicators, that the promotion is already done quite large.

Family Variable. Based on descriptive calculation of family indicator, that product purchase is done continuously and in the long run, that the dimensions of purchases that have been performed continuously and in the long run. Based on purchases any time indicator, that the intention to buy suffuciently. Based on continuous using indicator, that each of the dimensions remain in the same brand. Based on these indicators influence parents to buy the same brand, that parents are very influential in the selection of the brand dimension. Based on indicators of the opinion of parents and family, that the opinion of a parent influence the selection of the brand dimension. Based indicators of recommendation parents, that the recommendations of parents information is good enough.
Brand Awareness Variable. Based on descriptive calculation of brand awareness indicators, that surely Pepsodent toothpaste display easily recognizable. Based on indicators of the presence and recognition, that the presence of Pepsodent easily recognizable.

Brand Association Variabel. Based on descriptive calculation of data processing indicator, that the gap brand dimension is very strong. Based indicators of competitors Pepsodent visible difference of quality, that the quality dimensions of brand Pepsodent is different. That the dimensions of the symbol Pepsodent is easy to remember. Based on family brand personality indicator, it can be said that the dimensions Pepsodent have high brand personality.

Perceived quality Variable. Based on descriptive calculation of perceived quality indicators, that in the quality dimensions of Pepsodent is the best. High trust indicator based on the belief of high quality, that Pepsodent dimensional quality is believed. Based on quality indicators that the dimensions of Pepsodent is believed to be high quality. 
Table 5: Structural equation models output

\begin{tabular}{|c|c|c|}
\hline Variable & Variable & Value \\
\hline \multirow{3}{*}{ Advertising } & $\longrightarrow$ Brand Awareness & 0,08 \\
\hline & $\Longrightarrow$ Brand Association & 0,31 \\
\hline & $\rightarrow$ Perceived quality & 0,21 \\
\hline \multirow{3}{*}{ Price } & $\longrightarrow$ Brand Awareness & 0,43 \\
\hline & $\Longrightarrow$ Brand Association & 0,19 \\
\hline & $\rightarrow$ Perceived quality & 0,41 \\
\hline \multirow{3}{*}{ Promotion } & $\rightarrow$ Brand Awareness & 0,18 \\
\hline & & 0,29 \\
\hline & $\rightarrow$ Perceived quality & 0,22 \\
\hline \multirow{3}{*}{ Family } & $\longrightarrow$ Brand Awareness & 0,16 \\
\hline & $\longrightarrow$ Brand Association & 0,16 \\
\hline & $\longrightarrow$ Perceived quality & $-0,11$ \\
\hline
\end{tabular}

Source: Lisrel output

\section{Quantitative analysis}

Calculation of structural equation modeling using software GSCA (Generalized Structured Component Analysis), obtained the model FIT value that can only be said to explain the relationship to the entire variable models by $27 \%$. So if it is connected in the correlation relations have a fairly small effect. Can be said also that the models are made poorly if it is connected to each other. If the relationship between variables was adjusted (AFIT) diversity remains the model did not move much with the previous calculation of only $26.5 \%$ explanation.

Advertising variable determined by $50.9 \%$ of advertising indicator. Price variable determined by $54.3 \%$ of Pepsodent purchase price indicator. Promotion variable determined by $60.3 \%$ of Pepsodent campaign indicator. Family variables determined by $58.8 \%$ of parents indicator. Brand Awareness variable determined by $66.7 \%$ of toothpaste brand indicator. Brand association variabel determined by $34.3 \%$ of quality indicators. Perceived quality variable determined by $50.9 \%$ of Pepsodent has a higher quality.

Based on the above calculation, that the greatest influence is Price to Brand Awareness Variables whereas the smallest effect is Advertising to Brand Awareness Variables. While there is a negative relationship in the Family to Perceived quality. It could be argued that the price is still a fairly decisive variable for consumer awareness and perceived towards the purchase of Pepsodent toothpaste. While the family influence in Pepsodent toothpaste on determining Awareness,

\section{Discussion}

Based on the data on Table 7 that influence of advertising to brand awareness and brand association as well as perceived quality of the four studies that have been done in the moderate range. Even based on Gilaninia et al. (2012) advertising will reduce the perceived quality, although the effect is very small. Prices in this study has a strong influence to brand awareness and perceived qua- 
Tabel 6: SEM indicator fit and results

\begin{tabular}{|c|c|c|}
\hline Indicator & Fit & Result \\
\hline Chi square $\left(\chi^{2}\right)$ & Little & 107.43 \\
\hline Goodness of fit indices (GFI) & $0-1$ & 0.88 \\
\hline Adjusted Goodness of fit indices (AGFI) & 1 & 0.15 \\
\hline Parsimony Goodness of Fit Index (PGFI) & $>0,06$ & 0.094 \\
\hline Root Mean Square Error of Approximation (RMSEA) & $<0,05$ & 0.40 \\
\hline 90\% Confidence Interval for RMSEA & Little & 0.34 \\
\hline P-value for test of close fit & $<0,50$ & 0.00 \\
\hline Expected Cross Validation Index (ECVI) model : ECVI saturated & $<$ & 0.29 \\
\hline Expected Cross Validation Index (ECVI) model : ECVI independence & $<$ & 4.19 \\
\hline Akaike's Information Criterion (AIC) model : AIC saturated & $<$ & 56.00 \\
\hline Akaike's Information Criterion (AIC) model : AIC independence & $<$ & 846.68 \\
\hline Normed Fit Index (NFI) & $0-1$ & 0.87 \\
\hline Non- Normed Fit Index (NNFI) & $0-1$ & 0.065 \\
\hline Comparative Fit Index (CFI) & $0-1$ & 0.87 \\
\hline Incremental Fit Index (IFI) & 0,9 & 0.87 \\
\hline Relative Fit Index (RFI) & $0-1$ & 0.063 \\
\hline
\end{tabular}

Source: Lisrel output

Assumptions suggested in the above structural modeling output that fulfilled so that it can be said that the model is statistically acceptable.

Table 7: Previous studies compared with this research

\begin{tabular}{|c|c|c|c|c|c|}
\hline Variable & Correlated to & Gilaninia & Yoo & Gil & This research \\
\hline \multirow{3}{*}{ Advertising } & Brand Awareness & 0,18 & 0,34 & 0,19 & 0,08 \\
\hline & Brand Association & 0,23 & 0,34 & 0,19 & 0,31 \\
\hline & Perceived quality & $-0,05$ & 0,35 & 0,20 & 0,21 \\
\hline \multirow{3}{*}{ Price } & Brand Awareness & & $-0,21$ & & 0,43 \\
\hline & Brand Association & & $-0,21$ & & 0,19 \\
\hline & Perceived quality & & 0,09 & 0,22 & 0,41 \\
\hline \multirow{3}{*}{ Promotion } & Brand Awareness & & & & 0,18 \\
\hline & Brand Association & & & & 0,29 \\
\hline & Perceived quality & & & $-0,01$ & 0,22 \\
\hline \multirow{3}{*}{ Family } & Brand Awareness & 0,77 & & 0,65 & 0,16 \\
\hline & Brand Association & 0,75 & & 0,65 & 0,16 \\
\hline & Perceived quality & 0,81 & & 0,45 & $-0,11$ \\
\hline
\end{tabular}

Source: Data reprocessed 
lity compared with two other researchers. Effect of sales promotion is to brand awareness and brand association and perceived quality, while according to (Gil et al. (2007)) sales promotion will decrease, although small influence to perceived quality. Families have little effect in this study, even the perceived quality tends to degrade. But two other researchers showed that the family has a strong influence to raise the perceived of quality. This study find that promotion and price have signficant impact to brand awareness, but Conradie, R.L., and Klopper (2014) found no significant impact. The impact of promotion to perceived quality had mentioned by Faryabi et al. (2015) that price discount offer not to lower quality but to get more savings for consmers.

\section{MANAGERIAL IMPLICATIONS}

In advertising variable, in the advertising campaign cost effectiveness dimension found the lowest score that higher advertising costs larger than competitors indicators. It means the costs incurred to promote Pepsodent larger than competitors Unilever should convey promotion quality more than competitors so that good quality is always supported by good promotion. In the price variable, lowest score in cheap price dimension in found that Pepsodent demand do not increase if the price is cheap indicator. It means falling prices do not increase Pepsodent demand. Unilever should not issued Pepsodent cheap price version. In the promotion variable, in promotional costs dimensions found the cost more expensive than competitors indicator. It means that Unilever promotional costs impressed too expensive. Unilever should promote Pepsodent impressed with promotional quality. In the family variable, in the parents recommendation dimension found that parents recommend to use products indicator in the lowest score. It means that parents seldom recommend family products to be used. Unilever should show parents experience the benefits of Pepsodent. In the brand awareness Variable, that on top of mind when buying Pepsodent dimension, in the most remembered toothpaste is
Pepsodent indicator in the lowest score. It means that Pepsodent is not the only choice of toothpaste. Unilever should continue to provide advertising and promotional top of mind to their customers.

In the brand association variable, that in the assessment dimensions found that Pepsodent quality better than competitors indicators got the lowest score. It means Pepsodent quality is not better than competitors. Unilever should keep bringing the best quality can be compared with its competitors. In the perceived quality variable, in the confidence dimension, that Pepsodent is believed to be good quality got the lowest score. It means Pepsodent do not believed to be good quality. Unilever should always proof that their quality is the best

\section{CONCLUSION}

Advertising variable consisting of 3 dimensions and 6 indicators. The highest score is the advertising frequency dimension, but the highest score indicator that is better than the competitor's advertising is not on the above dimension. Price variable consisting of 3 dimensions and 6 indicators. The highest score is the price too expensive dimension that supported by the highest score indicator that if the price is expensive, consumers switch to another brand. Promotion variable consisting of 3 dimensions and 6 indicators. The highest score is the dimension of promotion frequency, but it is not supported by the highest indicator score that promotion has reached all cosnumers. Family variable consisting of 6 dimensions and 11 indicators. The highest score is brand loyalty dimension that is supported by the highest score that Pepsodent has been used for a long time indicator. Brand awareness variable consists of 3 dimensions and 6 indicators. The highest score is Pepsodent brand recognition dimension supported by the highest score that Pepsodent easily recognizable indicator. Brand association variable consists of 4 dimensions and 8 indicators. The highest score is brand impression dimension, but it is not supported by the highest 
score that Pepsodent easy to remember because it had been known since a long time indicator. Perceived quality variable consists of 3 dimensions and 6 indicator. The highest score is best quality dimension supported by the highest score that no doubt about Pepsodent quality indicator.

Very low corrrelation ranging from 0.00 to 0.19 found between brand awareness to advertising variables, price to brand association variables, promotion to brand awareness variables, family to brand awareness and brand association variables. While the family to perceived qualitys variables had opposite correlation. Low but definite correlation ranged from 0.20 to 0.39 found between advertising to brand association and perceived quality variables. Promotion to brand associations and perceived quality variables. Correlation ranged from 0.40 to 0.60 found between price to brand awareness and perceived quality variables.

REFERENCES

Bohrer, M. F. (2007). Discriminant analysis of Aaker's band equity on top of mind awareness. (Doctoral), Anderson, Anderson. Buschken, J. (2007). Determinants of brand advertising efficiency. Journal of Advertising, 36(3), 51-73.

Chiang, Y. S., \& Niu, H. J. (2013). Advertising expenditure and price asjoint indicators of product quality. International Management Review, 9(1), 78-88.

Conradie, E., R.L., M., \& Klopper, H. B. (2014). Brand awareness in the service sector influenced by eight internal marketing elements. Journal of Global Business Technology, 10(1), 25-37.

David, N. S. (2014). The use and misuse of structural equation modelling in management research: A review and critique. Journal of Advances in Management Research, 11(1), 47-81.

Deepa, S., \& Chitramani, P. (2013). Brand building of retail stores. Journal of Contemporary Research in Management, 8(2), $9-24$.

Faryabi, M., S.F., K., \& Saed, M. (2015). Brand name, sales promotion, and consumers' online purchase intention for cellphone brands. International Journal of Marketing Studies, 7(1), 167-179.

Ghozali, I. (2004). Model persamaan strukutral. Semarang: Badan Penerbit Undip.

Gil, R. B., Andres, E. F., \& Salinas, E. M. (2007). Family as a source of consumer based brand equity. Journal of Product and Brand Management, 16(3), 188-199.

Gilaninia, S., Delafrooz, N., \& Dokht, S. (2012). The role of family in creating brand equity from perpective of bank customers. Journal of Basic and Applied Scientific Research, 2(9), 8906-8911.

Jeong, J. (2004). Exploring the impact of advertising on brand equity and sharehorlder value. (Doctoral), Univerisity of Texas at Austin, Austin.

Jorgensen, S., Taboubi, S., \& Zaccoure, G. (2003). Cooperative advertising in a marketing channel. Journal of Optimization Theory and Applications, 110(1), 145-158.

Keller, K. L. (2003). Building, measuring, and managing brand equity (2 ed.). New Jersey: Prentice Hall.

Moore, E. S., Wilkie, W. L., \& Lutz, R. J. (2002). Passing the torch: Intergenarational influences as a source of brand equity. Journal of Marketing, 66(April), 17-37.

Norgaard, M. K., Bruns, K., Christensen, P. H., \& Mikkelsen, M. R. (2007). Children's influence on and participation in the family decision process during food buying. Emerrald Insight, 8(3), 197-216.

Shaharudin, M. R., Mansor, S. W., Hassan, A. A., Omar, M. W., \& Harun, E. H. (2011). The relationship between product quality and purchase intention. African Journal of Business Management, 5(20), 8163-8176. 
Swait, J., \& Erdem, T. (2022). The effects of temporal consistency of sales promotions and availability on consumer choice behavior. Journal of Marketing Research, 39(3), 304-320.

Villarejo, A. F., \& Sanchez-Franco, M. J. (2005). The impact of marketing communication and price promotion on brand equity. Journal of Brand Management, 12(6), 431-445.

Yoo, B., Donthu, N., \& Lee, S. (2000). An examination of selected marketing mix elements and brand equity. Academy of Marketing Science Journal, 28(2), 195-211.

Yoo, B., \& Dontu, N. (2001). Developing and validating a multidomensional consumer-based brand equity scale. Journal of Business Research, 52(1), 1-14. 